\title{
Interleukin 8 as a vaso-occlusive marker in Brazilian patients with sickle cell disease
}

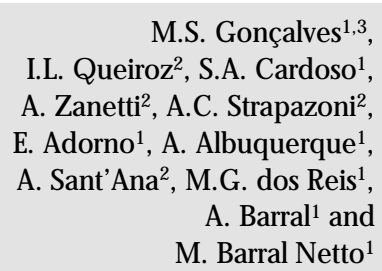

M.S. Gonçalves ${ }^{1,3}$,

I.L. Q ueiroz ${ }^{2}$, S.A. Cardoso ${ }^{1}$,

A. Zanetti2 ${ }^{2}$ A.C. Strapazoni²,

E. Adorno ${ }^{1}$, A. Albuquerque ${ }^{1}$,

A. Sant'Ana'2, M.G. dos Reis' ${ }^{1}$,

A. Barral ${ }^{1}$ and

M. Barral N etto ${ }^{1}$

\author{
${ }^{1}$ Laboratórios de Patologia e Biologia Molecular, and Imuno-Parasitologia, \\ Centro de Pesquisas Gonçalo Moniz, FIOCRUZ, Salvador, BA, Brasil

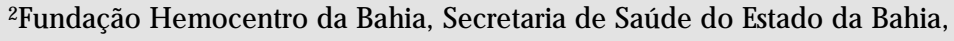 \\ Salvador, BA, Brasil \\ ${ }^{3}$ Faculdade de Farmácia, Universidade Federal da Bahia, Salvador, BA, Brasil
}

\author{
Correspondence \\ M.S. Gonçalves \\ Laboratório de Patologia e \\ Biologia M olecular \\ Centro de Pesquisas Gonçalo Moniz \\ Rua Valdemar Falcão, 121 \\ 40295-001 Salvador, BA \\ Brasil \\ E-mail: mari@cpqgm.fiocruz.br
}

Research supported by PAPES-FIOCRUZ (Nos. 0250250303 and 0250250304 ), PRONEX (No. 97376), and CN Pq

(Nos. 351856/92-7 and 521201/96-1).

Received April 18, 2001

Accepted July 31, 2001

\section{Abstract}

Sickle cell disease has a worldwide distribution and is a public health problem in Brazil. Although vaso-occlusive crisis (VOC) is one of the most important clinical features of the disease, there are still several steps of its pathogenesis which are unknown. The increase of the chemotactic factor interleukin 8 (IL-8) has been reported to be involved in sickle cell disease crisis, but this has not been demonstrated conclusively. In the present study we analyzed serum IL-8 levels by ELISA and hematological parameters and hemoglobin patterns by standard techniques in 23 (21 SS and $2 \mathrm{SC}$ ) Brazilian patients with sickle cell syndromes during VOC caused by different inducing factors, 22 (21 SS and $1 \mathrm{SC}$ ) sickle cell patients out of crisis, and 11 healthy controls. Increased IL-8 levels were observed in 19 of 23 VOC patients $(79.2 \%), 3$ of them with more than $1,000 \mathrm{pg} / \mathrm{ml}$. Seventeen of $22(77.3 \%)$ non-crisis patients showed low IL-8 levels (less than 15 $\mathrm{pg} / \mathrm{ml})$. Healthy controls had low IL-8 levels. A significant difference in serum IL-8 levels was observed between crisis and non-crisis sickle cell patients $(\mathrm{P}<0.0001)$. There was no correlation between IL-8 levels and hematological data or hemoglobin patterns. High serum IL-8 levels were observed in VOC patients independently of the crisisinducing factor. We conclude that in the studied population, IL-8 concentration may be a useful VOC marker, although the mechanism of the pathogenic process of sickle cell VOC syndromes remains unclear.

\section{Introduction}

Sickling disorders are characterized by the presence of sickle hemoglobin (HbS), which exhibits a point mutation at the sixth codon of the ß-globin gene ( $\underline{G} \underline{A G} \rightarrow \mathrm{GTG})$, encoding a valine instead of a glutamine in

\section{Key words}

- Interleukin 8

- Sickle cell syndromes

- Vaso-occlusive crisis 
by cell inflexibility, which is responsible for a variety of cell shapes and consequently for the vaso-occlusive phenomena described in the pathogenesis of the disease $(1,2)$. Sickle cell disease affects millions of people throughout the world and in Brazil the sickle cell trait (AS) occurs with a frequency of 6.9 to $15.4 \%$. The State of Bahia, in the Northeast region of the country, has the highest frequency of abnormal hemoglobin and the highest rate of race admixture, mainly of African origin, causing the presence of hemoglobinopathies to be considered a public health problem $(3,4)$.

Pain is the most common symptom in sickle cell disease. Acute painful cell episodes occur mostly in bone marrow, followed by microvascular occlusion. The long bones and joints are the most common pain sites, but the physiological origin of sickle cell disease is not yet well understood (5). Another clinical feature of sickle cell disease is acute chest syndrome (ACS), which is the most common cause of pulmonary diseases, causing $25 \%$ of the deaths of sickle cell disease patients $(6,7)$.

Sickle cell disease has several types of vaso-occlusive pain crises (VOC) such as abdominal and musculoskeletal crises and priapism. The VOC in sickle cell syndromes has been considered to be a process of a complex nature and an important cause of morbidity, which has been associated with several modulating factors, including RBC cell deformity and density, $\mathrm{KCl}$ co-transport and $\mathrm{Ca}^{2+}$ intravascular concentration, leukocyte and platelet alterations, endothelial cell biology, adherence, hemostatic activation, and reactivity of microvascular tone (8-14).

The role of chemokines, particularly interleukin 8 (IL-8) (15), as a VOC marker has not been well established, especially with respect to the pathogenic mechanism and its property as a VOC risk factor. Polymorphonuclear leukocytes (PMN) may be important as a pathogenic factor during VOC since an increased number of activated $\left(\mathrm{CD} 64^{+}\right) \mathrm{PMN}$ has been found in VOC sickle cell disease patients (16). The study of several adhesion molecules, such as CD11a, CD11b, CD11c/ CD18, L-selectin and CD15, as well as some interleukins such as granulocyte colonystimulating factor, granulocyte-macrophage colony-stimulating factor (GM-CSF), IL- $\alpha$, IL-1, IL-6 and IL-8 described as mediators of PMN binding to endothelium, did not show abnormal expression (15-22). In the present study, we evaluated serum IL-8 levels, hematological parameters and hemoglobin patterns in sickle cell syndrome patients in VOC and compared the results with nonVOC sickle cell disease patients and normal controls.

\section{Subjects and Methods}

A total of 23 (21 SS and 2 SC) sickle cell disease patients (10 males and 13 females) presenting VOC due to different inducing factors were studied, including 2 with priapism, 2 with abdominal crisis and 19 with musculoskeletal crisis. Samples were collected before any therapeutic intervention. The two control groups included in the study consisted of 22 (21 SS and 1 SC) sickle cell disease patients out of crisis (10 males and 12 females) and 11 healthy subjects ( 3 males and 8 females). All patients were from an outpatient clinic of Fundação Hemocentro da Bahia (HEMOBA), Salvador, BA, Brazil, ranging in age from 1 to 45 years. Patients or their guardians gave written informed consent allowing their participation in the study, previously approved by the Institutional Ethics Committee.

Hematological analysis was performed using an electronic cell counter (Coulter Counter T890). Red cell lysates were studied by electrophoresis on cellulose acetate strips at $\mathrm{pH}$ 8.4. The presence of $\mathrm{HbS}$ was confirmed using a positive sickling and solubility test followed by electrophoresis on agar-citrate, $\mathrm{pH}$ 5.3. Hemoglobin A2 was 
quantified by elution from cellulose acetate strips after electrophoresis at $\mathrm{pH} 8.4$ and fetal hemoglobin ( $\mathrm{HbF}$ ) levels were measured using an alkali denaturation procedure (23).

The serum IL-8 levels were measured by an enzyme-linked immunosorbent assay (ELISA) (Duoset-Genzyme, Cambridge, MA, USA) according to manufacturer instructions, which considered a level $\leq 15 \mathrm{pg} /$ $\mathrm{ml}$ as normal.

Data were analyzed statistically using the EPI Info version 6.0 and Graph Pad Prism software. A P value of less than 0.05 was considered to be statistically significant.

\section{Results}

Table 1 shows the hematological parameters of normal and sickle cell syndrome patients in VOC and out of crisis. Data are reported as means $\pm \mathrm{SD}$. There were significant differences between the three groups in HbF $(\mathrm{P}=0.0005), \mathrm{RBC}(\mathrm{P}<0.001)$, white blood cells $(\mathrm{P}=0.0006)$, hemoglobin $(\mathrm{P}<0.0001)$ and hematocrit $(\mathrm{P}<0.0001)$.

The data in Figure 1 indicate a significant increase in IL-8 levels in $19(82.6 \%)$ VOC patients, 3 of them with over $1,000 \mathrm{pg} / \mathrm{ml}$, and $4(17.4 \%)$ VOC patients had IL-8 levels below $15 \mathrm{pg} / \mathrm{ml}$. Seventeen (77.3\%) noncrisis patients had low IL-8 levels, and 5 (22.7\%) had IL-8 levels over $15 \mathrm{pg} / \mathrm{ml}$ (maximum of $87 \mathrm{pg} / \mathrm{ml}$ ). The healthy control subjects had low IL-8 levels and in some cases, undetectable levels. Figure 1 shows a scattergram of IL-8 level distribution for the three groups studied, showing a statistically significant difference between patients in VOC and out of crisis $(\mathrm{P}<0.0001$, KruskalWallis analysis).

There was no statistically significant correlation between hematological data, hemoglobin pattern and IL-8 levels in this population, even when $\mathrm{HbF}$ levels, considered as a prognostic clinical feature of the disease, were taken into account.

\section{Discussion}

The results demonstrate that the serum IL-8 levels of most sickle cell syndrome patients in VOC were higher than those of out of crisis patients and healthy controls. We did not find significant differences in hematological parameters or hemoglobin pattern analysis.

High IL-8 levels have been associated with several diseases such as pancreatitis (24), peripheral arterial occlusive disease

Table 1. Hematological parameters of normal subjects and sickle cell syndrome patients in vaso-occlusive crisis (VOC) and out of crisis, including the SS and SC genotypes.

\begin{tabular}{lccc}
\hline $\begin{array}{l}\text { Hematological } \\
\text { data }\end{array}$ & $\begin{array}{c}\text { Normal controls } \\
(\mathrm{N}=11)\end{array}$ & $\begin{array}{c}\text { VOC patients } \\
(\mathrm{N}=23)\end{array}$ & $\begin{array}{c}\text { Out of crisis patients } \\
(\mathrm{N}=22)\end{array}$ \\
\hline WBC $\left(\times 10^{9} / \mathrm{l}\right)$ & $6.667 \pm 1.326$ & $16.436 \pm 7.128$ & $13.606 \pm 8.0$ \\
$\mathrm{RBC}\left(\times 10^{12} / \mathrm{l}\right)$ & $4.674 \pm 0.321$ & $2.616 \pm 0.670$ & $2.451 \pm 0.526$ \\
$\mathrm{Hb}(\mathrm{g} / \mathrm{dl})$ & $13.500 \pm 0.950$ & $7.882 \pm 1.943$ & $7.150 \pm 1.257$ \\
$\mathrm{Ht}(\%)$ & $42.080 \pm 2.299$ & $24.965 \pm 6.085$ & $23.267 \pm 3.999$ \\
MCV (fl) & $90.178 \pm 5.308$ & $93.488 \pm 9.697$ & $96.161 \pm 8.916$ \\
MCH (pg) & $28.978 \pm 2.101$ & $29.076 \pm 4.159$ & $29.594 \pm 2.901$ \\
MCHC (g/l) & $32.020 \pm 0.908$ & $30.882 \pm 2.755$ & $30.778 \pm 1.530$ \\
HbF $(\%)$ & $1.364 \pm 0.329$ & $10.772 \pm 8.370$ & $11.741 \pm 7.098$ \\
\hline
\end{tabular}

The VOC group consisted of $21 \mathrm{SS}$ and $2 \mathrm{SC}$ patients and the out of crisis patient group consisted of $21 \mathrm{SS}$ and $1 \mathrm{SC}$ patients. The number of normal subjects was 11 . $\mathrm{P}<0.05$ is considered significant. WBC, RBC, white and red blood cells, respectively; $\mathrm{Hb}$, hemoglobin; $\mathrm{Ht}$, hematocrit; $\mathrm{MCV}, \mathrm{MCH}, \mathrm{MCHC}$, mean corpuscular volume, mean corpuscular hemoglobin and mean corpuscular hemoglobin concentration, respectively; $\mathrm{HbF}$, fetal hemoglobin.

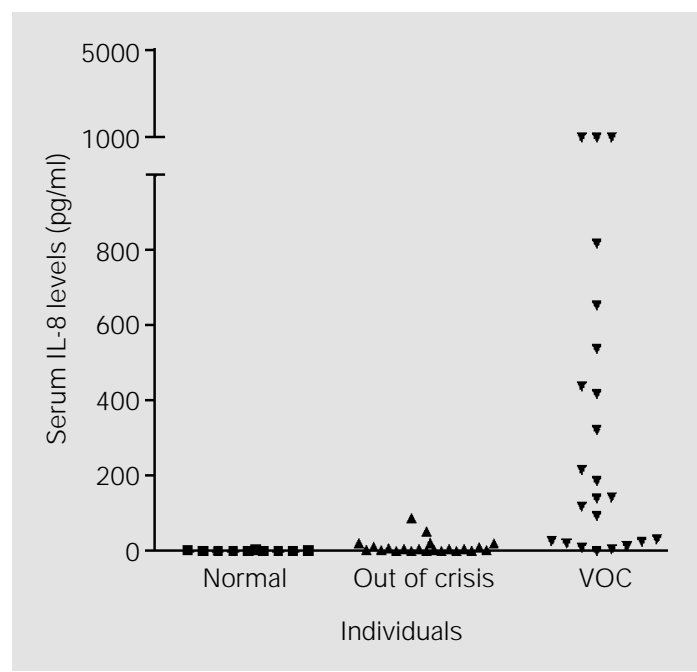

Figure 1. Scattergram showing ELISA analysis of the distribution of interleukin 8 (IL8) levels in the serum of 23 patients in vaso-occlusive crisis (VOC), 22 out of crisis, and 11 normal healthy subjects. The IL-8 levels of the VOC group were supranormal, while the out of crisis and the normal healthy subject groups had low IL-8 levels $(P<0.0001)$. 
(25), endometriosis (26), and myocardial infarction (27). High IL-8 expression has also been attributed to a calcitonin genepeptide, a neuropeptide with proinflammatory activity in human corneal epithelial cells (28).

High levels of IL-8 during sickle cell disease crisis and during painful crisis have been reported, independently of the crisisinducing factor (29). High levels of endothelin-1 and prostaglandin-E2 have also been described during painful crises in sickle cell patients in the absence of an increase of other mediators, such as TNF- $\alpha$, IL- $\alpha$, IL-6, IL-8 and IL-10 (30). Substance P, known as a TNF- $\alpha$ release stimulating factor and IL-8 promoter, has been reported to be present in high levels in sickle cell disease patients in VOC. The authors found increased IL-8 levels when these were compared to a normal control group, but there was no difference between crisis and out of crisis sickle cell disease patients (31).

High IL-8 levels were reported in serum and bronchoalveolar lavage fluid in a pediatric sickle cell patient group during ACS, suggesting that this cytokine may have a role in focal neutrophil activation (32). A drop in hemoglobin concentration from 1.6 to 2.25 $\mathrm{g} / \mathrm{dl}$ has been described in adult sickle cell patients with ACS, depending on hemoglobin genotype, as well as increased leukocyte counts of $9.2 \pm 8.3 \times 10^{9} / 1$, and platelet counts of $67 \pm 209 \times 10^{9} / 1$. In the present analysis of hematological and hemoglobin data, we did not find any significant differences between the groups studied, but it is important to state that our series did not include ACS patients (33). Cytokine re- sponses have been associated with erythropoiesis levels and clinical course of sickle cell disease. Sickle cell disease patients with high $\mathrm{HbF}$ levels ( $>8-9 \%$ ) had an equilibrium between the inhibitory (TGF- $\beta$ ), the stimulatory stem cell factor (SCF) and IL-3 factors that resulted in a moderate erythropoietic response. Patients with low $\mathrm{HbF}(<8 \%)$ had low levels of TGF- $\beta$ and an increase of GMCSF and SCF, maintaining an intense erythropoiesis followed by higher erythropoietic stress (34).

Despite all the controversial reports which reported different levels of the so-called modulating factors in sickle cell disease syndromes, our results demonstrate a significant change in IL-8 levels which was emphasized by the correlation of nonsymptomatic sickle cell patients and healthy controls. On the basis of our results, we conclude that the increased IL-8 levels could be considered as a marker of VOC risk in our population and that the finding of some VOC patients with low IL-8 levels may be related to specific crisis-inducing factors in association with the individual genetic background of each patient, since some genetic inheritance has been associated with the pathogenetic course of the disease (35). Further studies should be conducted in order to determine the exact point before VOC, when serum IL-8 levels begin to increase. This requires the monitoring of the IL-8 levels in sickle cell patients out of crisis, showing how rapidly these levels increase just before VOC development. The ELISA for IL-8 measurement can be performed quickly and can be included in the standard follow-up protocols for these patients.

\section{References}

1. Wang WC \& Luken J N (1998). Sickle cell anemia and other sickling syndromes. In: Lu GR, Lukens J N, Paraskavas F, Greer JP \& Rodegers GM (Editors), Wintrob's Clinical Hematology. Williams \& Wilkins, Baltimore.
2. Bun HF \& Forget BG (1986). Hemoglobin: Molecular, Genetic and Clinical Aspects. W.B. Saunders, Philadelphia.

3. Azevedo ES, Alves AFP, Silva MCBO, Souza MGF, Lima AMVMD \& Azevedo W (1980). Distribution of abnormal hemoglo- bin and glucose-6-phosphate dehydrogenase variants in 1200 school children of Bahia Brazil. American J ournal of Physical Anthropology, 53: 509-512.

4. Ramalho AS (1986). As Hemoglobinopatias Hereditárias. Um Problema de Saúde 
Pública no Brasil. Editora da Revista Brasileira de Genética, Ribeirão Preto.

5. Ballas SK (1997). Management of sickle cell pain. Current Opinion in Hematology, 4: 104-111.

6. Dreyer ZE (1996). Chest infection and syndromes in sickle cell disease of childhood. Seminars in Respiratory Infections, 11: 163-172.

7. Vishinsky EP, Styles LA, Wright EC, Castro O, Nickerson B \& Cooperative Study of Sickle Cell Disease (1997). Acute chest syndrome in sickle cell disease: Clinical presentation and course. Blood, 89: 1787-1792.

8. Billet $\mathrm{HH}$, Kim K, Fabry ME \& Nagel RL (1986). The percentage of dense red cells does not predict incidence of sickle cell painful crisis. Blood, 68: 301-303.

9. Ballas SK, Lamer J, Slith ED, Surrey S, Schwartz E \& Rappaport E (1988). Rheologic predictors of the severity of the painful sickle cell crisis. Blood, 72: 1216-1223.

10. Davies SC \& Brozovic M (1989). The presentation, management and prophylaxis of sickle cell disease. Blood Reviews, 3: 2944.

11. Kaul DK, Fabry ME \& Nagel RL (1989). Microvascular sites and characteristics of sickle cell adhesion to vascular endothelium in shear flow conditions: pathophysiological implications. Proceedings of the National Academy of Sciences, USA, 86: 3356-3360.

12. Kaul DK, Chen D \& Zhan J (1994). Adhesion of sickle cells to vascular endothelium is critically dependent on changes in density and shape of the cells. Blood, 10: 3006-3017.

13. Platt OS, Brambilla DJ , Rosse WF, Milner $\mathrm{PF}$, Castro O, Steinberg MH \& Klug PP (1994). Mortality in sickle cell disease. New England J ournal of Medicine, 330: 1639-1644.

14. Kanall C, Worthen G \& J onson G (1997). Interleukin 8 stimulated phosphatidylinositol-3-kinase activity regulates the migration of human neutrophils independent of extracellular signal-regulated kinase and p38 mitogen-activated protein kinases. Proceedings of the National Academy of Sciences, USA, 94: 3052-3057.

15. Lachant NA \& Oseas RS (1987). Case report: Vaso occlusive crisis-associated neu- trophil dysfunction in patients with sickle cell disease. American J ournal of the Medical Sciences, 294: 253-254.

16. Fadlon $\mathrm{E}$, Vordermeier S, Pearson T, MireSluis A, Dumonde D \& Brown K (1998). Blood polymorphonuclear leukocytes from the majority of sickle cell patients in crisis phase of disease show the enhanced adhesion to vascular endothelium and increased expression of CD64. Blood, 91: 266-273.

17. Bevilacqua MP (1993). Endothelial-leukocyte adhesion molecules. Annual Review of Immunology, 11: 767-804.

18. Cronstein BN \& Weissmann G (1993). The adhesion molecules of inflammation. Arthritis and Rheumatism, 36: 147-157.

19. Ruoslahti E \& Piershbacker MD (1987). New perspectives in cell adhesion: RGD and integrins. Science, 238: 491-497.

20. Lipowsky MG, Sheikh NA \& Katz DM (1987). Intravital microscopy of capillary haemodynamics in sickle cell disease. J ournal of Clinical Investigation, 80: 117127.

21. Kumar A, Eckman J R, Swerlick RA \& Wick TM (1996). Phorbol ester stimulation increases sickle cell erythrocytes adherence to endothelium: a novel pathway involving alpha 4 beta 1 integrin receptors on sickle reticulocytes and fibronectin. Blood, 88: 4348-4358.

22. Wick TM \& Eckman J R (1996). Molecular basis of sickle cell-endothelial cell interaction. Current Opinion in Hematology, 3: 118-124.

23. Dacie JV \& Lewis SM (1995). Practical Hematology. 8th edn. Churchill Livingstone, Edinburgh.

24. Messmann H, Voght W, Falk W, Vogl D, Zirngibl $H$, Leser HG \& Scholmerich J (1998). Interleukin and their antagonists but not TNF and its receptors are released in post-ERP pancreatitis. European J ournal of Gastroenterology and Hepatology, 10: 611-617.

25. Kirk G, Hickman P, McLaren M, Stonebridge PA \& Belch J J (1999). Interleukin-8 (IL-8) may contribute to the activation of neutrophils in patients with peripheral arterial occlusive disease (PAOD). European J ournal of Vascular and Endovascular Surgery, 18: 434-438.

26. Gazvani MR, Christmas S, Quenby S,
Kirwan J , J ohnson PM \& Kingsland CR (1998). Peritoneal fluid concentrations of interleukin-8 in women with endometriosis: relationship to stage of disease. Human Reproduction, 13: 1957-1961.

27. De Winter RJ, Manten A, de Joig YP, Adams R, Van Dwenter SJ \& Lie KI (1997). Interleukin 8 released after myocardial infarction is mainly bound to erythrocytes. Heart, 78: 598-602.

28. Tran MT, Ritchie MH, Lausch RN \& Oakes J E (2000). Calcitonin gene-related peptide induces IL-8 synthesis in human corneal epithelial cells. J ournal of Immunology, 164: 4307-4312.

29. Duits AJ , Schnog J B, Lard LR, Saleh AW \& Roger RA (1998). Elevated IL-8 levels during sickle cell crisis. European J ournal of Hematology, 61: 302-305.

30. Graido-Gonzalez E, Dohert J C, Bergreen EW, Organ G, Telfer M \& McMillen MA (1998). Plasma endothelin-1, cytokine, and prostaglandin E2 levels in sickle cell disease and acute vaso-occlusive sickle crisis. Blood, 92: 2551-2555.

31. Michaels LA, Ohene-Frempog $\mathrm{K}$, Zhao $\mathrm{H}$ $\&$ Douglas SD (1998). Serum levels of substance $P$ are elevated in patients with sickle cell disease and increase further during vaso-occlusive crisis. Blood, 92: 3148-3151.

32. Abboud MR, Habid D, Jackson S, Xu F, Brunson C, Laver J \& Ballas S (1997). Levels of interleukin-8 are elevated in patients with sickle cell disease during acute chest syndrome. Blood, 90 (Suppl 1): 2780 (Abstract).

33. Maitre B, Habibi A, Roudout-Thoraval F, Bachir D, Belghiti DD, Galacteros F \& Godeau B (2000). Acute chest syndrome in adults with sickle cell disease. Chest, 117: 1386-1392.

34. Croisart H \& Nagel RL (1999). Circulating response and the level of erythropoiesis in sickle cell anemia. American J ournal of Hematology, 60: 105-115.

35. Schoeder WA, Powars DR, Lay LM, Chan LS, Huynh V, Shelton J B \& Shelton J R (1989). $\beta^{S}$-clusters haplotypes, $\alpha$-genes status, and hematological data from SS, SC and Sß-thalassemia patients in Southern California. Hemoglobin, 13: 325-353. 